\title{
Barbara Ciciora
}

Book review:

Barbara Hryszko, «Le Peintre du Roi» Aleksander Ubeleski

- malarz polskiego pochodzenia we Francji i jego dzieła (Aleksander Ubeleski, "Le Peintre du Roi» - an Artist of Polish

Descent in France and his Oeuvre), Akademia Ignatianum w Krakowie - Wydawnictwo WAM, Kraków 2016, 412 pages, 147 illustrations, 8 Tables, Appendices (29 appendices A, 26 appendices $\mathrm{B})$, a chronology of the artist's life, a full catalogue of his works; A4 format

Readers of Barbara Hryszko's previous articles ${ }^{1}$ are used to her precise accounts of the system of artistic education in Paris in the second half of the $17^{\text {th }}$ and early $18^{\text {th }}$ centuries, to her in-depth iconographic analyses, and to

B. Nowak, Aleksander Ubeleski (1649-1718) w Królewskiej Akademii Malarstwa i Rzeźby w Paryżu - edukacja i działalność dydaktyczna, in: Polskie szkolnictwo artystyczne. Dzieje - Teoria - Praktyka. Materiały LIII Ogólnopolskiej Sesji Naukowej Stowarzyszenia Historyków Sztuki, Warszawa, 14-16 października 2004, ed. M. Poprzęcka, Warszawa 2005, pp. 79-95; B. Hryszko, Rola narzędzia w praktyce malarza akademickiego na wybranych przykładach sztuki francuskiej XVII wieku, in: Narzędzie, ed. A. Giełdoń-Paszek (Folia academiae), Katowice 2010, pp. 4251; B. Hryszko, Rola malarstwa historycznego w utrwalaniu pamięci o przeszłości - peinture d'histoire w służbie króla Ludwika XIV, in: Kultura - pamięć - edukacja, scientific editing by A. P. Bieś, M. Chrost, B. Topij-Sempińska, Kraków 2011, pp. 337-353; B. Hryszko, Podróż artystyczna Aleksandra Ubeleskiego z Paryża do Rzymu, in: Barok. Historia, literatura, sztuka, Vol. XX/2, 2013, pp. 47-58; B. Hryszko, Sposoby gloryfikacji władcy w malarstwie na przykładzie ikonografii Ludwika XIV, "Estetyka i Krytyka", vol. XXIX, 2013, pp. 79-97; B. Hryszko, Echa doktryny potrydenckiej w twórczości Aleksandra Ubeleskiego, in: Sztuka po Trydencie, ed. K. Kuczman, A. Witko, (Studia de Arte Moderna, vol. 1), Kraków 2014, pp. 179192; B. Hryszko, Malarska narracja w świetle teorii francuskiej sztuki akademickiej. Antecendencje wolności artystycznej, "Rocznik Historii Sztuki", vol. XXXIX, 2014, pp. 61-72; B. Hryszko, A Painter as a Draughtsman. Typology and Terminology of Drawings in Academic Didactics and Artistic Practice in France in the 17th Century, in: Metodologia, metoda i terminologia grafiki i rysunku. Teoria i praktyka, ed. J. Talbierska, Warszawa 2014, pp. 169-176; B. Hryszko, Alexandre Ubeleski 
her competent syntheses about the techniques and tools used in French painting from that period, all of them interesting mainly because they were based on profound knowledge of archival texts related to the Royal Academy of Painting and Sculpture in Paris. The more absent the issues discussed and analysed by Barbara Hryszko are from Polish scholarly literature, the more valuable the texts are to Polish art historians ${ }^{2}$. They are also a basis for achieving a profound understanding of the specificity of Polish $18^{\text {th }}$ and $19^{\text {th }}$ century painting and its correct systematisation and classification, necessary for comprehending it in the context of European artistic movements and trends. Most of them, after all, persisted - to a greater or lesser extent, but invariably - with the chosen principles of artistic doctrine codified and popularised in Europe precisely thanks to $17^{\text {th }}$-century Paris. The new subject matter introduced to Polish art history by Barbara Hryszko meant that her doctoral thesis, devoted to the works of Aleksander Ubeleski, an artist of Polish origin who was active in Paris at the turn of the $17^{\text {th }}$ and $18^{\text {th }}$ centuries, was highly anticipated ${ }^{3}$.

Finally, after many critical attributive analyses of Ubeleski's oeuvre, the book came out in 2016. Its contents strictly match the title of the book; its subject matter is clearly systematised and refers to the artist and his work. The extensive monograph does not contain any broad contexts of the epoch, as if the author assumed that the readers interested in them can learn about

(Ubelesqui): The Oeuvre of the Painter and the Definition of his Style, "Artibus et Historiae. An Art Anthology", vol. LXXIV, 2015, pp. 225-280; B. Hryszko, Od sacrum do profanum. Desakralizacja Île de la Cité w Paryżu w XVIII i XIX wieku, in: Sacrum w mieście: wymiar kulturowy, religijny $i$ społeczny, vol. II, Epoka nowożytna i czasy współczesne, ed. D. Quirini-Popławska, Ł. Burkiewicz, Kraków 2016, pp. 131-155; B. Hryszko, Principles of the theory of art. Governing propaganda imagery of the Sun King, Barok. Historia, literatura, sztuka, vol. XXIII/1-2, 2016, pp. 197-207.

2 Until Barbara Hryszko published her articles and the book reviewed here, neither primary nor secondary texts about the activity of the Parisian Royal Academy of Painting and Sculpture in the $17^{\text {th }} \mathrm{c}$. were available in Polish. The academic theory and practice in Paris at that time was previously discussed in most detail in two publications: K. Secomska, Spór o starożytność. Problemy malarstwa w "Paralelach" Perrault, Warszawa 1991 and Teoretycy, historiografowie i artyści o sztuce 16oo-17oo, selected and edited by J. Białostocki, scientific edition and addendums by M. Poprzęcka and A. Ziemba, Warszawa 1994.

3 The doctoral thesis Życie i twórczość malarza Aleksandra Ubeleskiego $\left(1649 / 165^{1-}\right.$ 1718) [The Life and Work of the Painter Aleksander Ubeleski, 1649/51-1718], vols 1-2, Kraków 2008 (printout of the thesis, written under the supervision of Prof. dr hab. Marcin Fabiański of the Institute of Art History, Jagiellonian University, Kraków). 
them from her previous articles. The text is divided into four main sections: I. the artist's biography, II. a concise, but still over-70-page-long analysis of his artistic activity, III. visual documents (a full catalogue of the artist's works) and IV. archival documents.

The book opens with the Preface (pp. 19-24) with a short introduction presenting the artistic milieu in which the painter worked ${ }^{4}$ and the state of research on the artist, unknown in Poland, on whose works (mentioned in guidebooks on $18^{\text {th }}$-century Paris and $19^{\text {th }}$-century reviews of heritage objects and dictionaries of artists) the attention of French art historians researching the activity of the Parisian Academy was focused in the 1980 s. However, it was not until Aleksander Ubeleski's works were sold on the antiquarian market, including ones wrongly attributed to him, that Pierre Rosenberg looked more closely at the figure of the Parisian Academic and attempted to establish the number of his works for the first time. Attributive studies, caused by the situation on the antiquarian market, later dominated reflections on the painter's works. It was also the direction (quite obvious for conducting further reliable studies on Ubeleski's oeuvre) that Barbara Hryszko's studies took when she prepared her doctoral thesis and continued her research, which a few years later produced the excellent result of establishing the attributive criteria, according to which she identified 78 of Ubeleski's paintings and drawings. Later on in the Preface, the author presents the concept behind the book, which is the right decision in light of the assumptions of readers of her previous publications, who were expecting to receive a complete picture of Aleksander Ubeleski and his milieu; a sort of opus magnum, even if reason told them that archival and attributive research was too time-consuming to write a comprehensive, multi-contextual monograph about the Parisian Academic as early as at this stage. The last part of the Preface presents the places where archival, museum and library queries were conducted, as well as the persons and institutions who assisted in the preparation of the final version of the publication.

4 Artistic, literary, political and nationalist ideas in which 17th-century French Academics were involved (and Aleksander Ubeleski's artistic work was set in) were already analysed by Krystyna Secomska in an excellent book entitled Spór o starożytność. Problemy malarstwa w "Paralelach" Perraulta, Warszawa 1991. This is the publication Barbara Hryszko cites in her numerous articles, such as Rola malarstwa historycznego..., pp. 344-351; Sposoby gloryfikacji władcy..., p. 81; Malarska narracja $w$ świetle teorii..., pp. 64, 68. 
Biographical information is collected in the part entitled Life (pp. 2780), divided into four sub-chapters: 1. Polish descent, family and milieu, 2. Artistic education in the Royal Academy of Painting and Sculpture in Paris until 1672, 3. Studies in Rome in 1673-1679, and 4. Private life and work in 16791718. Polish readers of the book were especially agitated by the artist's Polish descent; doubting the artist's Polish roots, they claimed that Aleksander Ubeleski's ancestors had come from the territory of $16^{\text {th }}$-century Lithuania, present-day Belarus, i.e. not from Poland, disregarding the fact that this problem had been thoroughly examined and explained by the author by means of consulting specialists in anthroponymy. The author also cited equally reliable voices in the ongoing discussion on the topic, including Auguste Jal's guess from 1867, later questioned by French art historians, about Belarus as the artist's place of origin. However tempting it might be to solve the mystery of Ubeleski's family descent, the task of confirming Barbara Hryszko's proposal should be undertaken by historians, who - using their methodological knowledge and experience with archival queries - have historically frequently supported art historians (suffice it to mention their invaluable help with establishing the birthplace of Wit Stwosz ${ }^{5}$. Other problems, related to archival queries regarding the artist's biography rather than his family's genealogy, are solved by the author independently. Today, quite a few problems are caused by Ubeleski's biography, from the very beginning of his life; for instance, the documents in the Bibliothèque Nationale de France and publications from the period as well as dictionaries of artists provide

The dispute between Polish and German historians about the nationality and birthplace of Wit Stwosz went on for a hundred years; see S. Muthesius, Polski czy niemiecki? Aspekty kulturalno-polityczne polemiki wokół Wita Stwosza, in: Wit Stwosz - Veit Stoß. Artysta w Krakowie i Norymberdze, München 200, pp. 102-115, also M. Rożek, Mistrz dziwnie stateczny. Biografia artysty, in: Wit Stwosz w Krakowie, ed. L. Kalinowski, F. Stolot, Kraków 1987, pp. 32-33. It started to die down after WWII thanks to the archival studies carried out by Bolesław Przybyszewski, who established that Stwosz was born in Horb on the Neckar; see B. Przybyszewski, Nieznane pochodzenie dotyczace Wita Stwosza, "Biuletyn Historii Sztuki", vol. XIV, 1952, No. 2, pp. 62-66; B. Przybyszewski, Pochodzenie Wita Stwosza w świetle krakowskich źródeł archiwalnych, "Archiwa, Biblioteki i Muzea Kościelne", vol. 46, 1983, pp. 393-400; Cracovia artificium. Supplementa. Krakowskie środowisko artystyczne czasów Wita Stwosza, selected and edited by B. Przybyszewski, Wrocław-Warszawa-Kraków 1990, p. 77; see also S. Rospond, Wit Stwosz. Studium językowe, Wrocław 1966. It should be remembered that the dispute concerned an issue which was easier to solve - the roots of the artist famous in Kraków and Nuremberg, not his family, who had emigrated centuries before. 
contradictory information about his date of birth. Aleksander made intriguing changes to his surname; he first spelt his Polish-sounding name so that its French pronunciation would resemble the Polish ("Ubelesqui"), but later started to write it in a way closer to the Polish spelling, as "Ubelesky" interchangeably with "Ubeleski", i.e. with the characteristic ending "-ski". French Academics contemporaneous to him who knew him personally called him a Pole, as attested by the phrase "le Polonais Alexandre Ubeleski" in the description of the Salon of 1699 (p. 30, footnote 34).

Ubeleski's artistic career proceeded smoothly and properly, along the path intended by the authorities of the Royal Academy of Painting and Sculpture in Paris, but the contradiction inherent to his artistic work can be regarded as one of its greatest mysteries. On the one hand, there is its unproblematic beginning and studies which culminated in the highest prize, the Prix de Rome, his quick acceptance among the Parisian Academics, and his talent reflected in his free drawings and excellent académies; on the other hand, there are his paintings, most of which, especially the ones created in the $17^{\text {th }}$ century, are similar in concept, composition and even the type of figures to the works of Charles Le Brun. The ones commissioned by the director of the Academy and probably painted under his supervision are, as a rule, average or even imitative. This contradiction is difficult to accept per se. Should we look for its roots in the problem which Krystyna Secomska defined as an excess of academic préceptes positifs, which deprived students of the Royal Academy studying under the supervision of Le Brun of their independent thinking ${ }^{6}$ ? This observation may be confirmed by a procedure described by Barbara Hryszko in the sub-chapter Artistic education in the Royal Academy of Painting and Sculpture in Paris until 1672, which consisted in forcing outstanding students, who were sent to Rome, to incessantly copy Roman works of art without the opportunity to develop their own invention. This led to protests, which were quelled by ... even stricter rigor. Perhaps it would be worth checking whether Ubeleski's artistic decisions were not crucially influenced by an excess of supervision by the principal who commissioned academics to paint but in return wanted his own concepts brought to life.

The second part of the book is divided into four chapters: 1. Establishing the oeuvre, 2. Artistic style, 3. The origins of artistic work, and 4. 
Iconographic problems. The author collected documents and carried out studies to verify Ubeleski's oeuvre with limitless patience. To this end, she took advantage of detailed analyses: a graphological analysis of the signatures visible on drawings and paintings attributed to Ubeleski, which she presented in tables; a comparative analysis - when comparing prints with existing paintings and drawings; she also analysed descriptions of works in collections, collectors' remarks, and tapestries and prints created on the basis of the artist's non-surviving works. The author analysed the formal features of Ubeleski's paintings and drawings in just as much detail in order to define the artist's style; to this end she expertly and effortlessly used the knowledge of the techniques used at various stages of work required by the academy in the process of creating a work of art understood as an oil painting. Despite the author applying her broad knowledge to attributive analyses, the reader and viewer continues to be surprised by the considerable diversity of the style of drawings in comparison to the limited diversity of the style of oil paintings. In the case of the latter, this situation may be explained by the artist's dependence either on his academic patron and his clientele or, conversely, on the preferences of the Parisian audience unconnected to the academy. In the case of his drawings, such dependence did not exist. However, we should also account for the burgeoning collectors' market for drawings and graphics and the emergence of a situation where the artist may have taken note of the individual tastes of collector. Barbara Hryszko emphasises the significance of an important fact - the diversity of the drawing techniques used by Ubeleski and the resultant formal differences among the drawings. The author then identifies a set of the most popular gestures and motifs which the artist used as self-quotations in his various compositions. The question arises: did other artists from the group of Charles Le Brun's collaborators also use the same repertoire of poses, gestures, colour solutions and compositions in their pursuit of emphasising the importance of academic concepts among artists educated at the Parisian academy, or was this repertoire also used by artists who were loosely or not at all associated with it?

The origins of artistic work are presented in a very synthetic manner in comparison to the meticulous analyses in the two previous parts of the chapter. The author identifies technical and formal analogies in drawings and paintings of $17^{\text {th }}$-century Parisian artists, analysing the types of work characteristic for the individual stages of creating a work, which were developed in the Parisian academy: académies, premières pensés, études, 
desseins, modelli and oil paintings. Barbara Hryszko notes the greatest number of analogies between the works of Ubeleski and Charles Le Brun, his teacher and patron, and Noël Coypel, during whose short-lived directorship of the academy Ubeleski was studying in Rome and with whom he later maintained a professional and social relationship. From Le Brun he adapted mainly the method of creative work as well as the oil painting and pen-and-ink drawing technique, and from Coypel - the use of sanguine and elements of style. Ubeleski adopted compositional solutions both from Classical Antiquity and early modern Italian works, especially Rafael and Annibale Carracci, preserved in among others the Villa Farnesina, the Capitol collections and the Borghese Family collections. The choice of collections and masterpieces of Italian artists to which Ubeleski referred in his paintings clearly reveals classical models, which in the second half of the $17^{\text {th }}$ century were used to train the hand, style and composition of young students of French painting. We do not know, however, whether the shown analogies with works of French painters are typical only for academics or if they appear in the works of painters from outside this milieu and to what extent the Italian inspirations were the result of Ubeleski's own interests versus the practice of teaching at the Academy of Saint Luke in Rome ${ }^{7}$, adapted by the Parisian academy.

The inspiration with regard to composition, concepts and motifs listed by Barbara Hryszko in quite a lot of detail - was drawn by the artist mainly from contemporaneous French art. They reflected the artist's erudition and he selected them according to the system of genres of academic painting. A painting which belonged to a lower genre may have had fewer classical elements and more free ones, chosen according to the artist's and client's taste. When Ubeleski borrowed formal solutions, he frequently did so from the paintings of Nicolas Poussin, which were highly valued at the academy and recommended to students during conférences, but most often from the paintings of Charles Le Brun. In the case of his principal's works, he also copied the human physiognomy, facial expressions and the

7 In the teaching practice, the method of using classical masterpieces as models for the studying artists for shaping figures in paintings (the disegno dal nudo and the related disegno dall'antico) was one of the most important elements of education at the Roman Academy of Saint Luke until almost the mid-19 ${ }^{\text {th }}$ C.; see M. Nitka, Twórczość malarzy polskich w papieskim w Rzymie w XIX wieku, Warszawa-Toruń 2014, pp. $168-182$. 
background architecture shown in them. He also made references to works created in Le Brun's workshop. The scope, scale and number of references is so considerable that we can safely say that he also belonged to this workshop himself.

In the next part of the chapter, entitled The influence of academic theory, we can find the most important principles of the academic theory held at the Parisian academy in the second half of the $17^{\text {th }}$ century, which was compulsory for its students and in particular for the director's collaborators. The knowledge of the principles helps us understand the consequences of the strict discipline with regard to obeying doctrinal restrictions imposed by the director and theoreticians associated with the Academy on the young students of the art of painting and, consequently, on the art created in the milieu of Le Brun's Academy. The requirement of the artist's intellectual involvement assumed that the work was created in the artist's mind according to an idea, i.e. it was primarily the result of intellectual work. Therefore, the painter's invention was of fundamental importance for his art. The theory included a number of recommendations related to the valuing of genres of painting, as well as requirements which deeply interfered with the stages of the creative process. The point of reference for artists was supposed to be the art of Classical Antiquity, including emulating poses and motifs. The form of the work was supposed to be appropriate for the topic (decorum, understood in a way close to the ancient modes of depiction), e.g. when depicting great, heroic events the style was supposed to be high. The principle of decorum was accompanied by the principle of bienséance (propriety), according to which the freedom of individual choice of motifs and invention was acceptable in genres which were less valued and in paintings with light, even frivolous subjects, which still belonged to the genre of peintre d'historire. The principle of probability, vraisemblance, in the $17^{\text {th }}$ century was limited to the anatomical correctness of figures, while using the ancient canon of human figures and somewhat idealising the figure and facial features. Idealisation also occurred when composing the scene, including the setting in which the storia unfolded, and therefore also the way of depicting nature divested of natural, realistic, non-idealised views. The principle of disegno, which the Italians applied on many levels, according to Le Brun's expectations was supposed to ensure that the scene and presented elements were readable and that the boundaries of adding colour (which played a subordinate function to the lines and three-dimensionality of the elements presented in the painting) were in place. Movement and emotions, 
the last of the fundamental principles of painting, were to be expressed mainly through body movement, poses and gestures, carefully selected and theatrically emphasised, to make it easier for the viewer to guess the feelings of the depicted person, as analysing the frame of mind, emotions and psychological reactions was one of the favourite aspects of $17^{\text {th }}$-century perception of works of art. Facial expressions were of lesser importance, especially in the light of the requirement to show ideally beautiful faces. Ultimately, the painting was supposed to evoke the impression of harmony in the viewer (light, colour, visual tensions). The author briefly analyses these principles with reference to Ubeleski's work and concludes that: "the [painter's - B.C.] art is an almost textbook example of painting faithful to the Academic ideals" (p. 129).

The admirable persistence of the majority of the mentioned principles usually enabled artists to achieve diverse results, even though actual restrictions on invention existed. Meanwhile, the academic theory strictly enforced by Le Brun had an effect on Ubeleski's work, which was a welcome novelty in $17^{\text {th }}$-century French art but largely disappointed some of his contemporaries, who were surprised that it was impossible to draw aesthetic satisfaction from it, and consequently discredited his works by assessing them as average (p. 80) ${ }^{8}$. Therefore, analysing Ubeleski's work as an element of the process of adapting classical art in France, both in epistemological and aesthetic terms, is worth another research effort.

The fourth part of chapter II, entitled Iconographic problems, is devoted to the subjects of Aleksander Ubeleski's works. In this area as well, Barbara Hryszko had to show her scrupulousness and perseverance in identifying iconographic depictions, both painted and drawn. The following example she describes is not the only one: The subject of the drawing, so far based on a pre-iconographic description and referred to as The Pope Sitting on a Throne under a Palace Portico turned out to be the subject of Scipio's Abstinence (p. 132). Ubeleski created very few (just eight) allegorical and historical works, only one of which is known in the final form of an oil painting; it is entitled The King Offering Peace to Europe - an Allegory of the

8 K. Secomska, Spór o starożytność..., op. cit., pp. 18-19. This complaint was not addressed only at Ubeleski. Jean-Baptiste Dubos wrote that Nature, which Louis XIV bent to his will so many times, decisively refused to obey him on this point. It was not willing to produce many gifted painters in his times, as it had done of its own accord in the times of Leo X (ibid., p. 154). 
Peace of Nijmegen in 1678 . Paintings of this genre were rarely commissioned, usually by the king or the Royal Academy, and as such they were enormously prestigious. Judging by the titles given to Ubeleski's known paintings, their main subject was supposed to be variously depicted glorification of the ruler, Louis XIV. This task was in line with the king's expectation of academy's artists for their works to glorify himself and his deeds ${ }^{9}$. Creating paintings with such a specific and demanding goal in mind, Ubeleski reached for the repertoire of official comparisons, developed by the academy and accepted by the Royal Court, which ensured the academy's safety and the painter's comfort of work. Louis XIV appeared in pictures directly as himself (scenes from the history of France) or hidden under the guise of figures from ancient history, usually Alexander the Great, or mythology, e.g. Apollo. Even paintings seemingly far from topics related to the monarchy, such as An Allegory of Poetry, were covertly praising his nobleness, benevolence and protection of men of letters. Religious topics are also present in the artist's works, both as the genre of peinture d'histoire and in the form of devotional and mystical scenes. He created his works on the basis of the academic doctrine advocating that content should be conveyed in a clear way; he also followed the Jesuits' recommendations (e.g. Louis Richeôme) that paintings should help with meditating on the truths of faith and stimulate the piousness of God's people. He also included the didactic function of paintings, recommended by Franciszek Salezy. The complicated iconographic and ideological content created by Ubeleski, going far beyond the narration presented on the canvas, is described by the author succinctly and in a very interesting manner. Mythological topics, very important in $17^{\text {th }}$-century European painting, are represented in Ubeleski's oeuvre, which has survived to this day in only four paintings and six drawings. The source of the topics, typical for the period, were Ovid's Metamorphoses; the artist frequently surprised his viewers by choosing less popular scenes, such as Apollo and Issa or Aurora Seducing Cephalus. Their iconography is equally as rich and complicated as that of his religious scenes. It required the artist and his audience to have the knowledge of a wealth of mythological symbolism. It was only rarely that Ubeleski painted genre scenes, which Barbara Hryszko divided into three topics: musical, pastoral and elegant cy...; also K. Secomska, Spór o starożytność..., op. cit., pp. 14, 72. 
(p. 146). Some works referred to traditional allegories of the senses, such as hearing; others - like the elegant scenes - to the everyday life of the upper class. These works, which seemed to be devoid of deep ideological content, making their reception easier for a less educated audience, included the majority of the paintings exhibited in the Salons of 1699 (An Old Woman Bringing a Letter to a Young Girl Playing the Flute) and 1704 (four paintings entitled The Viola Player). However, the superficiality of the message is only seeming, which is shown by an analysis of the drawings entitled A Folk Dance and A Shepherd Playing the Flute. The depicted enjoyment, combining musical and love motifs, exists in a timeless and unreal space and refers the scene to the idylls and ideas about idyllic life known from ancient mythology. The love motif is supposed to be an allegory for sensuous love seeking happiness in eroticism. It also anticipates a change in the public's mentality, the predilection for uncomplicated, erotic topics typical of the times of French Rococo.

In conclusion, Barbara Hryszko's publication deserves the greatest attention of not only early modern art historians but also readers interested in iconography, artistic education and the theory of art academies. The source and analytic database collected by the author while studying the artist's work can be a basis for further syntheses, carried out without the risk of oversimplifications or anachronisms. The database also has enormous potential for broadening the knowledge related to showing Aleksander Ubeleski's oeuvre in various contexts, such as the activity of the Academy of Painting and Sculpture in Paris or classicising changes in French and European art of the $17^{\text {th }}$ century. We therefore remain hopeful that the author will devote her further studies and future publications to these problems. 